\title{
ANALISIS MARGIN OF SAFETY \\ USAHA PETERNAKAN PUYUH "MERRYLAND" \\ DI DESA KALI KECAMATAN PINELENG KABUPATN MINAHASA
}

\author{
Lisa Wangefela, N. M. Santa*, A. H. S. Salendu, L. S. Kalangi
}

Fakultas Peternakan Universitas Sam Ratulangi Manado, 95115

\begin{abstract}
ABSTRAK
Tujuan dari penelitian ini yaitu, 1). Untuk mengetahui titik impas usaha ternak puyuh "Merryland" 2). Untuk mengetahui margin of safety usaha ternak puyuh "Merryland". Lokasi penelitian dilakukan pada usaha ternak puyuh Merryland Farming di desa Kali Kecamatan Pineleng Kabupaten Minahasa, dengan pertimbangan bahwa usaha tersebut merupakan usaha perseorangan yang telah berjalan lebih dari $>3$ tahun, dengan jumlah kepemilikan ternak puyuh 5000 ekor. Penelitian ini dilaksanakan selama 1 bulan sejak tanggal 10 Desember 2016 sampai dengan 10 Januari 2017. Metode yang digunakan yaitu metode studi kasus, berupa data primer dan data sekunder. Data primer yaitu data yang diperoleh dari wawancara langsung dengan responden melalui daftar pertanyaan yang sudah disediakan. Data sekunder diperoleh instansi-instansi yang berhubungan dengan penelitian, seperti Kantor Desa, Kantor Kecamatan, Kantor Dinas Pertanian/Peternakan. Berdasarkan hasil penelitian diketahui bahwa, Usaha ternak puyuh "Merryland" telah mencapai titik impas pada penjualan telur puyuh 690.732 butir telur atau pada penjualan Rp259.589.665. Apabila peternak mengalami penurunan dalam penjualan telur, maka jumlah yang masih ditolerir agar peternak tidak mengalami kerugian yaitu $58,8 \%$ dari total penjualan.
\end{abstract}

Kata kunci : Puyuh, Margin Of Safety

*Korespondensi (corresponding author):

Email: nansisanta@unsrat.ac.id
ABSTRACT

$\begin{array}{llr}\text { ANALYSIS OF SAFETY } & \text { MARGIN ON } \\ \text { "MERRYLAND" } & \text { QUAIL } & \text { POULTRY } \\ \text { FARM AT } & \text { KALI } & \text { VILLAGE } \\ \text { PINELENG } & \text { DISTRICT } & \text { OF } \\ \text { MINAHASA REGENCY. } & \end{array}$

The purpose of this study was to determine the break-even point of "Merryland" quail poultry farm and to determine the margin of safety of this farm. The research location was at the "Merryland" quail poultry farm on Kali village Pineleng district of Minahasa regency, with the consideration that the venture is a private farm enterprise. This farm enterprise had been operated more than 3 years. The number of birds held were 5000 chicken quail. This study was conducted during one month from December 10, 2016 to January 10, 2017. The method was applied using the case study method, in the form of primary data and secondary data. Primary data were using data obtained from interviews with the respondents through a list of questions that had been provided. Secondary data were obtained using variables at the office related to research data, including the Village Office, District Office, and Office of the Department of Agriculture / Animal Husbandry. Based on the survey, results indicated that quail poultry farm of "Merryland" had reached breakeven sales of 690,732 quail eggs or on sale of IDR259,589,665. If the breeder declined in egg sales, the number of eggs tolerated of farmers not sufferin economic losses were $58.8 \%$ of the total sales.

Keywords : Quail, Margin Of Safety 


\section{PENDAHULUAN}

Sektor pertanian khususnya peternakan puyuh merupakan salah satu usaha yang mampu menyediakan bahan pangan sebagai sumber protein hewani asal telur. Menurut Handarini et al., (2008), peternakan burung puyuh merupakan salah satu sektor peternakan yang paling efisien dalam menyediakan daging dan telur serta merupakan bahan makanan sumber hewani yang bergizi tinggi. Telur puyuh yang dihasilkan melalui peternakan burung puyuh, menambah variasi pilihan bagi masyarakat dalam pemenuhan bahan pangan sumber protein hewani selain telur ayam ras dan ayam kampung yang umumnya dikenal masyarakat.

Tim Karya Tani Mandiri (2009), keunggulan daging ternak burung puyuh yaitu mengandung protein $13,1 \%$ dan lemak $11,1 \%$, dimana kandungan tersebut lebih baik dibandingkan ternak unggas lainnya khususnya ayam ras dan itik petelur. Keunggulan lainnya yaitu, dapat berproduksi dalam usia muda, memiliki siklus reproduksi singkat dan tidak memerlukan lahan yang luas untuk mengusahakannya. Listiyowati dan Roospitasari (2007), menambahkan bahwa ternak puyuh memiliki nilai jual yang tinggi di setiap tingkat umur, termasuk telur konsumsi, telur tetas bahkan ternak puyuh afkir.
Diketahui bahwa populasi ternak puyuh di Minahasa tahun 2015 sebesar 100.975 ekor, menunjukkan bahwa usaha ternak puyuh berpotensi untuk dikembangkan, karena jumlahnya masih kurang dari ternak unggas lainnya. Selain peluang dari segi konsumen atau proses pasar yang cukup menjanjikan, berusaha ternak burung puyuh juga termasuk usaha dengan modal investasi yang fleksibel karena dapat dimulai dengan modal kecilkecilan. Dengan demikian jelas bahwa beternak burung puyuh merupakan suatu peluang usaha yang menjanjikan di masa depan.

Beberapa penelitian telah dilakukan sebelumnya pada usaha ternak puyuh diantaranya oleh Arianti dan Suryani, (2013) yang mendapati bahwa usaha burung puyuh dapat memberikan tambahan pendapatan bagi keluarga. Sedangkan penelitian tentang peternakan puyuh di Sulawesi Utara telah dilakukan oleh Panekenan et al., (2013) di Kecamatan Sonder Kabupaten Minahasa, yang mendapatib ahwa peternak yang mengusahakan burung puyuh sebanyak 1000 ekor memperoleh keuntungan ratarata sebesar Rp 50.987.460/periode produksi.

Peternakan burung puyuh lebih banyak dilakukan secara pribadi dalam skala rumah tangga, dan dapat dijadikan 
usaha permanen yang memberikan tambahan pendapatan bagi masyarakat Anugrah et al., (2009).

Penelitian-penelitian

tersebut menjelaskan bahwa usaha ternak puyuh mampu memberikan keuntungan bagi peternak. Potensi pengembangan usaha ternak puyuh beserta manfaat yang diperoleh bagi peternak, membuktikan bahwa usaha ternak puyuh dapat dikembangkan sebagai suatu usaha untuk menambah pendapatan rumah tangga.

Terdapat peternakan puyuh Merryland yang terletak di desa Kali Kecamatan Pineleng Kabupaten Minahasa telah mengusahakan ternak puyuh sejak tahun 2014, dengan jumlah kepemilikan pada awal usahanya yaitu 1000 ekor. Peternak mengusahakan ternak puyuh khusus menjual telur. Peternak mengembangkan usahanya dengan meningkatkan jumlah kepemilikian ternak puyuh sehingga pada tahun 2016 telah memiliki burung puyuh sebanyak 5.000 ekor. Permasalahannya, jumlah penjualan telur puyuh pada waktu tertentu pada tahun 2016 khususnya bulan April dan September terjadi penurunan karena adanya pesaing baru yang juga menjual telur puyuh.

Penurunan jumlah penjualan pada suatu usaha dapat terjadi sewaktu-waktu. Keadaan tersebut erat hubungannya dengan keuntungan dan titik impas suatu usaha.
Menurut Ahmad (2000), suatu usaha mencapai titik impas apabila jumlah penerimaan sama dengan pengeluaran. Jika jumlah penerimaan lebih besar dari pendapatan, maka usaha tersebut memperoleh keuntungan. Selanjutnya dijelaskan bahwa jika suatu usaha dapat mengalami penurunan penjualan namun masih mampu berada pada keadaan titik impas,posisi usaha tersebut berada pada margin of safety.

Berdasarkan uraian tersebut, penelitian tentang analisis margin of safety pada usaha peternakan puyuh "Merryland" perlu dilakukan. Margin of safety dapat digunakan sebagai informasi bagi peternak apabila pada suatu saat terjadi penurunan pada jumlah telur yang akan dijual. Maka dirumuskan masalah dalam penelitian ini yaitu berapakah jumlah penurunan penjualan telur puyuh yang dapat terjadi pada usaha ternak puyuh "Merryland" di desa Kali Kecamatan Pineleng Kabupaten Minahasa agar tidak mengalami kerugian.

Tujuan dari hasil penulisan ini yaitu; Untuk mengetahui titik impas usaha peternakan puyuh "Merryland" dan untuk mengetahui margin of safety usaha ternak puyuh "Merryland".

\section{MATERI DAN METODE}

Lokasi penelitian ditentukan secara sengaja pada usaha ternak puyuh 
Merryland Farming di desa Kali Kecamatan Pineleng Kabupaten Minahasa, dengan pertimbangan bahwa usaha tersebut merupakan usaha perseorangan yang telah berjalan lebih dari 3 tahun, dengan jumlah kepemilikan ternak puyuh 5000 ekor. Penelitian ini dilaksanakan selama 1 bulan sejak tanggal 10 Desember 2016 sampai dengan 10 Januari 2017. Sedangkan pengumpulan data dalam penelitian ini menggunakan metode studi kasus. Data yang diambil berupa data primer dan data sekunder. Data primer yaitu data yang diperoleh dari wawancara langsung dengan responden melalui daftar pertanyaan yang sudah disediakan. Data sekunder diperoleh instansi-instansi yang berhubungan dengan penelitian, seperti Kantor Desa, Kantor Kecamatan, Kantor Dinas Pertanian/Peternakan. Adapun tujuan pertama penelitian ini yaitu untuk mengetahui titik impas usaha ternak puyuh "Merryland", menggunakan rumus Ahmad (2000) :

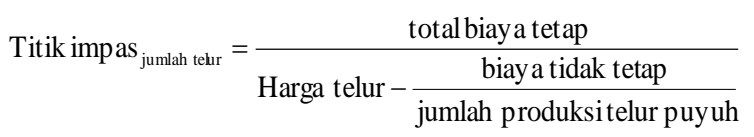

Titik impas $_{\text {rupiah }}=\frac{\text { total biay a tetap }}{1-\frac{\text { biay a tidak tetap }}{\text { jumlah penerimaan telur puyuh }}}$ Tujuan kedua penelitian ini yaitu untuk menghitung margin of safety (MOS) usaha ternak puyuh "Merryland" (Ahmad, 2000) Keterangan :

$$
\begin{array}{ll}
\text { JPT } & =\text { jumlah penjualan telur puyuh } \\
\text { JPTimpas }= & \text { jumlah penjualan telur puyuh pada titip } \\
& \text { impas }
\end{array}
$$

\section{HASIL DANPEMBAHASAN}

\section{Keadaan Usaha Ternak Burung Puyuh} "Merryland"

Usaha peternakan puyuh "Merryland" yang berlokasi di Desa Kali Kecamatan Pineleng Kabupaten Minahasa, usaha peternakan ini dibangun sejak tahun 2014 dan sampai sekarang ini masih dijalankan, berarti usia dari usaha peternakan ini kurang lebih 3 tahun. Pemilik peternakan puyuh tersebut adalah Bapak Alfriets Loway, berusia 44 tahun, dengan latar belakang pendidikan sebagai Mahasiswa.

\section{Pembibitan}

Peternak menggunakan bibit DOQ yang diperoleh dari perusahaan bibit yang ada di Jogjakarta pada tahun 2014. Biaya pembelian bibit DOQ sebesar Rp5.000,lekor. Namun tahun 2015 peternak mendapatkan bantuan berupa 2 unit mesin tetas, berupa mesin tetas tester kapasitas 300 butir dan mesin tetas besar kapasitas 4000 butir. Tahun 2014, peternak mendapatkan bantuan bibit dari Fakultas Peternakan melalui kegiatan pengabdian kepada masyarakat Lainawa et al., (2015). Peternak melakukan pembibitan secara mandiri, dengan menggunakan bibit yang diperoleh dari Filipina kemudian dikawinkan dengan betina lokal. 


\section{Kandang dan Perlengkapan}

Bangunan kandang dari usaha peternakan ini berjumlah 1 unit, dengan ukuran bangunan kandang yaitu panjang $25 \mathrm{~m}$, lebar $4 \mathrm{~m}$, tinggi $2,5 \mathrm{~m}$. Bangunan kandang tersebut didalamnya terdapat kandang baterei dengan ukuran $120 \mathrm{~cm}$ x $60 \mathrm{~cm} \times 180 \mathrm{~cm}$, dan jumlah kandang baterei yaitu 50 unit dengan masing-masing unit berisi 100 ekor ternak puyuh lengkap dengan tempat makan dan minum.

Untuk kandang starter ukuran $60 \mathrm{~cm} x 20 \mathrm{~cm} \times 40 \mathrm{~cm}$ sebanyak 20 unit kapasitas daya tampung 150 - 200 ekor puyuh. Kandang juga dilengkapi dengan fasilitas seperti, lampu, kabel, sakelar. Lampu yang digunakan yaitu lampu pijar 20 watt (kandang DOQ) dan lampu 10 watt (kandang layer).Lampu pijar selain berguna untuk alat penerangan pada waktu malam, berguna untuk memanaskan dan menghangatkan suhu ruangan di dalam kandang agar puyuh tidak kedinginan.

\section{Pakan dan Air Minum}

Ada 2 jenis pakan yang digunakan dengan harga yang cenderung sama, yaitu puyuh yang berumur 1-4 minggu diberi pakan starter ayam broiler (pakan DOQ), dan ternak puyuh setelah 4 minggu diberi pakan layer merek Shinta. Untuk pemberian pakan dilakukan pagi dan sore. Rata-rata konsumsi ternak puyuh umur 1-4 minggu yaitu 20 gram/ekor/hari, sedangkan ternak puyuh umur 5-8 minggu mengkonsumsi pakan 30 gram/ekor/hari.

Hasil penelitian Achmanu et al., (2011) menunjukan konversi ransum pakan burung puyuh adalah 2,45. Tingginya konversi ransum karena puyuh masih produksi pada awal produksinya dan belum mencapai umur puncak produksi. Makund et al., (2006) menjelaskan juga bahwa, pemberian pakan pada umur 9-19 minggu dengan kandungan energi $2700 \mathrm{Kkal} / \mathrm{kg}$ konversi pakannya adalah 3,34, sedangkan pada kandungan energi $2900 \quad \mathrm{Kkal} / \mathrm{kg}$ konversi pakan tidak berbeda yaitu 3,34.

Air minum pada ternak di perusahaan ini diberikan secara tidak terbatas (ad libitium), yaitu wadah air minum harus terus terisi air. Oleh karena itu, jika wadah air minum tampak airnya tinggal sedikit maka harus diisi lagi hingga penuh, yang berasal dari perusahaan air minum (PAM).

\section{Tenaga Kerja}

Peternakan puyuh petelur ini memiliki anggota tenaga kerja 1 orang, dengan aktivitas setiap harinya dijelaskan pada tabel 1 berikut.

Setiap bulannya, tenaga kerja yang digunakan sebanyak 1 orang tenaga kerja dengan jumlah gaji sebesar Rp2.800.000,- 
Tabel 1 . Aktifitas dan Jumlah Waktu Kerja Pada Usaha Ternak Puyuh

\begin{tabular}{ccl}
\hline No & Jam Kerja & Aktifitas \\
\hline 1 & $07.00-08.00$ & $\begin{array}{l}\text { Pembersihan kandang, memberi pakan dan air minum untuk } \\
\text { seluruh puyuh. } \\
2\end{array}$ \\
3 & $08.00-09.30$ & $\begin{array}{l}\text { Istrahat. } \\
\text { Angkat telur, pemilihan telur, pembersihan telur, } \\
\text { mengunpulkan feses/kotoran puyuh untuk dijadikan pupuk. }\end{array}$ \\
\hline 4 & $12.00-02.30$ & Pemasaran telur \\
\hline & &
\end{tabular}

\section{Pencegahan Penyakit, Pengobatan dan}

\section{Sanitasi Kandang}

Pemberian obat-obatan dan vitamin ini diberikan 1 bulan sekali, obatdan vitamin yang diberikan adalah Puyuh Medi EGG. Agar kebal dari penyakit yang disebabkan virus, puyuh diberi vaksinasi ND (Newcastle Disease), vaksinasi ND ini diberikan pada saat puyuh umur 1 hari (DOQ). Biaya pembelian obat dan vitamin sebesar Rp600.000,-, dan untuk biaya vaksinasi yaitu Rp300.000,-.

\section{Pemasaran}

Produk telur puyuh dijual di daerah kota Tomohon, kota Manado, kota Bitung, Minahasa dan Sanger Talaud. Selain itu telur dijual di dalam perusahan saja atau pembeli datang langsung membeli telur di perusahaan. Telur yang dihasilkan dalam sehari adalah 2000 - 4000 butir, harga jual telur Rp. 400,-s/d Rp. 450,-/butir atau dijual dalam kemasan 1 pak berisi 20 butir dengan harga Rp8.000/pak. Penjualan telur puyuh ini sesuai dengan harga pemasaran, bisa dikatakan harga fluktuatif atau berubah-ubah/naik turun. Burung puyuh mulai berproduksi yaitu 40 hari, jadi jumlah telur puyuh yang dijual selama 17 bulan sebesar 1.680 .000 butir telur atau sebesar 84.000 paktelur.

Selain menjual telur, peternak juga menjual puyuh afkir dengan harga Rp5.000,-Rp7.500,-/ekor. Jumlah puyuh afkir selama 1 periode yaitu 4.500 ekor.Selain itu, peternak juga menjual kotoran puyuh seharga Rp1.000/kg, dengan total produksi kotoran sebesar 10 karung per periode.

\section{Biaya dan Keuntungan Usaha Ternak Puyuh "Merryland"}

Biaya yang digunakan pada usaha ternak puyuh Merryland yaitu biaya tetap dan biaya tidak tetap, sedangkan penerimaan berupa penjualan telur, burung puyuh afkir dan kotoran, seperti yang dijelaskan pada tabel 2 dan 3 berikut. 
Tabel 2. Jumlah Biaya Investasi Penerimaan Usaha Ternak Puyuh "Merryland"

\begin{tabular}{clc}
\hline No & Keterangan & Jumlah \\
\hline 1 & Bahan Bangunan Kandang & Rp53.776.000 \\
2 & Perlengkapan Kandang & Rp50.075.980 \\
3 & Lahan & Rp75.000.000 \\
4 & Mesin Tetas & Rp10.000.000 \\
\hline & & Rp188.851.980 \\
\hline
\end{tabular}

Tabel 3. Jumlah Penerimaan dan Biaya Usaha Ternak Puyuh "Merryland"

\begin{tabular}{|c|c|c|}
\hline No & Keterangan & Jumlah \\
\hline \multirow[t]{5}{*}{ I } & Biaya Tetap & \\
\hline & Biaya Penyusutan Kandang dan Peralatan & Rp15.577.757 \\
\hline & Biaya Penyusutan Mesin Tetas & Rp 3.000 .000 \\
\hline & Lahan & Rp75.000.000 \\
\hline & Total & Rp93.577.797,- \\
\hline \multirow[t]{7}{*}{ II } & Biaya Tidak Tetap & \\
\hline & Pakan & Rp390.600.000 \\
\hline & Obat & $\mathrm{Rp} \quad 900.000$ \\
\hline & Tenaga Kerja & $\mathrm{Rp} 50.400 .000$ \\
\hline & Plastik & Rp 16.400 .000 \\
\hline & Air & $\mathrm{Rp} \quad 900.000$ \\
\hline & Total & Rp444.400.000 \\
\hline \multirow[t]{5}{*}{ III } & Penerimaan & \\
\hline & Total Penjualan telur & Rp672.000.000 \\
\hline & Total Penjualan puyuh afkir & $\operatorname{Rp} 22.500 .000$ \\
\hline & $\begin{array}{l}\text { Total penjualan kotoran } 10 \text { karung }(40 \mathrm{~kg} \text { ) } \\
\text { @ Rp1000/kg }\end{array}$ & $\mathrm{Rp} \quad 400.000$ \\
\hline & Total & Rp694.900.000 \\
\hline
\end{tabular}

Usaha ternak puyuh "Merryland" yang ada di desa Kali, mendapatkan keuntungan selama satu periode produksi yaitu;

$$
\begin{aligned}
\text { Keuntungan }= & \text { total penerimaan }- \text { total } \\
& \text { biaya } \\
= & \mathrm{Rp} 694.900 .000-(\mathrm{Rp} \\
& 93.577 .797,-+(\mathrm{Rp} \\
& 444.400 .000,-) \\
= & \mathrm{Rp} 694.900 .000-\mathrm{Rp} \\
& 537.977 .797 \\
= & \mathrm{Rp} 156.922 .203 / \text { periode } \\
= & \mathrm{Rp} 8.717 .900 / \mathrm{bulan}
\end{aligned}
$$

\section{Analisis TitikImpas Usaha Ternak Puyuh "Merryland"}

Analisis titik impas diperlukan untuk mengetahui hubungan antara produksi, volume penjualan, harga jual, biaya produksi, biaya lainnya baik bersifat tetap maupun variabel. Perhitungan titik impas jumlah butir telur dan penjualan usaha ternak puyuh, dijelaskan sebagai berikut : 


$$
\begin{aligned}
\text { Titik impas }_{\text {butir telur }}= & \frac{\text { total biay a tetap }}{\text { harga telur/butir }-\frac{\text { total biay a tidak tetap }}{\text { jumlah penjualan butir telur }}} \\
& =\frac{\operatorname{Rp} 93.577 .797}{400-\frac{\operatorname{Rp} 444.400 .000}{1.680 .000}} \\
& =\frac{\operatorname{Rp} 93.577 .797}{400-265} \\
& =\frac{\operatorname{Rp} 93.577 .797}{135} \\
& =690.732 \text { butir telur }
\end{aligned}
$$

$$
\begin{aligned}
\text { Titik impas }_{\text {rupiah }}= & \frac{\text { total biay a tetap }}{1-\frac{\text { total biay a tidak tetap }}{\text { total penerimaan usaha puy uh }}} \\
& =\frac{\operatorname{Rp} 93.577 .797}{1-\frac{\operatorname{Rp} 444.400 .000}{\operatorname{Rp} 694.900 .000}} \\
& =\frac{\operatorname{Rp} 93.577 .797}{1-0,6395} \\
& =\frac{\operatorname{Rp} 93.577 .797}{0,3605} \\
& =\operatorname{Rp} 259.589 .665 \text { rupiah }
\end{aligned}
$$

\section{Analisis Margin of Safety Usaha Ternak Puyuh "Merryland"}

Hasil perhitungan titik impas diatas, selanjutnya akan digunakan untuk menghitung margin of safety (MOS) usaha ternak puyuh "Merryland". Perhitungan tersebut menggunakan beberapa persamaan di bawah ini.

Perhitungan MOS jumlah butir telur :

MOS

$$
\begin{aligned}
& =\frac{\text { Jumlah telur yang dijual }- \text { jumlah telur posisiimpas }}{\text { Jumlah telur yang dijual }} \\
& =\frac{1.680 .000-690.732}{1.680 .000} \times 100 \% \\
& =58,8 \%
\end{aligned}
$$

Berdasarkan hasil perhitungan tersebut diatas, diketahui bahwa titik impas usaha ternak puyuh "Merryland" pada jumlah butir telur yaitu 690.732 butir telur, sedangkan titik impas rupiah pada penerimaan Rp 259.589.665,-

\section{KESIMPULAN}

Dari hasil penjelasan diatas dapat disimpulkan bahwa;

1. Usaha ternak puyuh "Merryland" telah mencapai titik impas pada penjualan telur puyuh 690.732 butir telur atau pada penjualan Rp259.589.665,--

2. Apabila peternak mengalami penurunan dalam penjualan telur, maka jumlah yang masih ditolerir agar peternak tidak mengalami kerugian yaitu $58,8 \%$ dari total penjualan.

\section{DAFTAR PUSTAKA}

Achmanu., Muharlien., dan Salaby. 2011. Pengaruh Lantai Kandang (Rapat Dan Renggang) Dan Imbangan Jantan-Betina Terhadap Konsumsi Pakan, Bobot Telur, Konversi Pakan Dan Tebal Kerabang Pada Burung Puyuh. Jurnal Ternak Tropika. 12 (2) :1-14.

Ahmad, K. 2000. Akutansi Manajemen: Dasar-Dasar Konsep Biaya Dan Pengambilan Keputusan, Edisi Pertama, Cetakan Ketiga, PT. Raja Grafindo Persada, Jakarta.

Anugrah, I.S., I. Sadikin, W.K. Sejati. 2009. Kebijakan Kelembagaan Usaha Unggas Tradisional Sebagai Sumber Ekonomi Rumah Tangga Pedesaan. Jurnal Analisis Kebijakan Pertanian. 7 (3) : 249267

Arianti R., S. Suryani. 2013. Studi Kelayakan Pengembangan Peternakan Puyuh Di Kecamatan Tenayan Raya Pekanbaru-Riau. Jurnal Ekonomi, Manajemen Dan Akutansi. 20 (1) : 73-92

Handarini, R., E. Saleh, B. Togatorop. 2008. Produksi Burung Puyuh yang Diberi Ransum Dengan 
Penambahan Tepung Umbut Sawit Fermentasi. Jurnal Agribisnis Peternakan. 4 (3): 107.

Lainawa J., N.M. Santa, J. Pandey, dan B. Bagau. 2015. Pemanfaatan Sumberdaya Lokal Sebagai Bahan Baku Industri Dan Pakan Alternatif Dalam Meningkatakan Pendapatan Ternak Puyuh Organik Di Kecamatan Sonder, Kabupaten Minahasa. Prodising Seminar Nasional Biodiversitas.

Listiyowati, E. dan K. Roospitasari. 2007. Puyuh Tata Laksana Budi Daya Secara Komersial. Edisi Revisi. Jakarta: Penebar Swadaya

Makund K.M., A.B Mandal, A.V Elangovan dan S Kaur. 2006. Response of laying japanese quailto dietary calcium levels at two levels energy. The Journal of Poultry Science. 43 : 351-356.

Panekenan, O.J., J.C. Loing, B. Rorimpandey dan P.O.V. Waleleng. 2013. Analisis Keuntungan Usaha Peternakan Puyuh Di Kecamatan Sonder Kabupaten Minahasa. Jurnal Zootek. 32 (5) : 1-10.

Tim Karya Tani Mandiri. 2009. Pedoman Budidaya Beternak Burung Puyuh. Bandung, Nuansa Aulia. PT Aji Parama. 